\title{
Investigation of minor psychiatric symptoms in patients with chronic kidney disease on hemodialysis treatment
}

\author{
Investigação de sintomas psiquiátricos menores em pacientes renais crônicos \\ em tratamento hemodialítico
}

\author{
Caio Henrique Rangel Silva ${ }^{1}$, Vanessa de Albuquerque Citero ${ }^{2}$, Daniel Pereira Coqueiro ${ }^{3}$, Noemi Peres Honorato ${ }^{4} \bowtie$ \\ Residência Multiprofissional em Saúde Mental da Faculdade de Medicina de Marília (FAMEMA). Marília, SP, Brasil. \\ 2 Departamento de Psiquiatria e Psicologia Médica da Universidade Federal de São Paulo (UNIFESP). São Paulo, SP, Brasil. \\ Departamento de Educação Física da Faculdade de Ensino Superior do Interior Paulista(FAIP). Marília, SP, Brasil. \\ ${ }^{4}$ Departamento de Psicologia Hospitalar da FAMEMA. Marília, SP, Brasil.
}

How to cite this article:

Silva CHR, Citero VA, Coqueiro DP, Honorato NP. Investigation of minor psychiatric symptoms in patients with chronic kidney disease on hemodialysis treatment. Sci Med. 2018;28(2):ID29538. http://doi.org/10.15448/1980-6108.2018.2.29538

\section{ABSTRACT}

AIMS: To identify sociodemographic characteristics and presence of minor symptoms of anxiety and depression in patients on hemodialysis.

METHODS: Cross-sectional study, carried out in the hemodialysis units of the Santas Casas de Misericórdia in Marília and Tupã, São Paulo state, Brazil, with 65 hemodialytic patients, ranging from 20 to 86 years. Initially, the mental state of the participants was evaluated in order to ensure they had conditions to understand the research objectives and to respond to the evaluation instruments. Following, the subjects answered to the socio-demographic and clinical questionnaire and the Hospital Anxiety and Depression Scale. The data were organized using relative and absolute frequencies for the categorical variables, and measures of central tendency and dispersion for the quantitative variables. In order to compare the mean scores according to the studied variables, unpaired Student's $t$ test and Analysis of Variance were used in addition to Mann Whitney U-Test and Kruskal-Wallis test when the distribution did not present normality. The adopted level of significance was $5 \%(\mathrm{p}<0.05)$.

RESULTS: The Hospital Anxiety and Depression Scale for minor symptoms identified 42 patients with anxiety and 45 with depression. The anxiety mean scores were statistically higher in the female $(10.23 \pm 4.51)$ than in the male $(8.32 \pm 3.68)$ patients $(\mathrm{p}=0.034)$. Patients aged 31 to 41 years and 42 to 52 years had higher depression scores $(12.20 \pm 1.48$ and $11.16 \pm 2.50$ respectively) when compared to patients aged over 52 years $(9.23 \pm 3.63)$ and aged 20 to 30 years $(5.50 \pm 2.12)(\mathrm{p}=0.017)$. Patients who underwent psychotherapeutic treatment had lower scores of anxiety $(1.00 \pm 1.41)$ compared to those who had already undergone psychotherapeutic treatment and those had never been under treatment $(9.27 \pm 3.92$ and $12.75 \pm 3.40$ respectively) $(\mathrm{p}=0.020)$. CONCLUSIONS: According to the Hospital Anxiety and Depression Scale, women had higher anxiety mean scores than men. The lowest scores for anxiety and depression were present in the younger and older age groups of women, and those who underwent psychotherapy presented even lower scores. Clinical management in psychotherapy can be a positive contribution to ease the symptoms of anxiety and depression, improving the patients' ability to cope with hemodialysis.

KEYWORDS: chronic renal disease; hemodialysis; depression; anxiety; psychotherapy.

\section{RESUMO}

OBJETIVOS: Identificar características sociodemográficas e a presença de sintomas menores de ansiedade e depressão em pacientes em hemodiálise. MÉTODOS: Estudo transversal, realizado nas unidades de hemodiálise das Santas Casas de Misericórdia em Marília e Tupã, estado de São Paulo, com 65 pacientes hemodialíticos, na faixa de idade entre 20 a 86 anos. Inicialmente, foi realizada avaliação do estado mental a fim de identificar se os pacientes estavam em condições de compreender os objetivos da pesquisa e de responder ao questionário sociodemográfico e clínico e a Escala de Ansiedade e Depressão Hospitalar. Os dados foram organizados utilizando frequências relativas a absolutas para as variáveis categóricas e medidas de tendência central e dispersão para as variáveis quantitativas. Para comparação dos escores médios segundo as variáveis estudadas foram utilizados teste t de Student não pareado e Análise de Variância, além do Teste U de Mann Whitney e do teste de Kruskal-Wallis quando a distribuição não apresentava normalidade. O nível de significância adotado foi de $5 \%(\mathrm{p}<0,05)$.

RESULTADOS: A Escala de Ansiedade e Depressão Hospitalar para sintomas menores identificou 42 pacientes com ansiedade e 45 com depressão. As médias dos escores de ansiedade apresentaram-se maiores nas mulheres $(10,23 \pm 4,51)$ do que nos homens $(8,32 \pm 3,68)(p=0,034)$. Os pacientes com idades de 31 a 41 anos e 42 a 52 anos apresentaram escores de depressão mais elevados (respectivamente 12,20 $\pm 1,48$ e 11,16 $\pm 2,50$ ) quando comparados aos pacientes com idades acima de 52 anos $(9,23 \pm 3,63)$ e com idades entre 20 e 30 anos $(5,50 \pm 2,12)(\mathrm{p}=0,017)$. Os pacientes que realizam tratamento psicoterápico tiveram escores de ansiedade menores $(1,00 \pm 1,41)$ em comparação aos que já haviam realizado o tratamento psicoterápico e aos que não tiveram essa intervenção (respectivamente $9,27 \pm 3,92$ e 12,75 $\pm 3,40)(p=0,020)$.

CONCLUSÕES: Conforme a Escala de Ansiedade e Depressão Hospitalar, as mulheres apresentaram, em média, escores de ansiedade maiores. Os menores escores para ansiedade e depressão estavam presentes nas faixas etárias mais jovens e mais velhas, e os que faziam ou já haviam feito psicoterapia apresentaram escores menores. O manejo clínico em psicoterapia pode ser uma contribuição positiva para amenizar os sintomas de ansiedade e depressão, melhorando a capacidade dos pacientes no enfrentamento do tratamento hemodialítico.

DESCRITORES: doença renal crônica; hemodiálise; depressão; ansiedade; psicoterapia. 
Abbreviations: CKD, chronic kidney disease; HADS, Hospital Anxiety and Depression Scale; HT, hemodialysis treatment.

\section{INTRODUCTION}

In middle nineteenth century, Richard Bright, a renowned clinician at Guy's Hospital in London, described a disease characterized by edema and, at autopsy, the presence of various anomalies that pointed to complications in hypertension, such as left ventricular hypertrophy and cerebral hemorrhages. In addition, in this disease, named Bright's Disease, kidneys often had a contracted and granular aspect, which we now know to be characteristic of Chronic Kidney Disease (CKD). Being an evolutionary disease, the symptoms are discrete in its onset. However, they can progress to their terminal phase. Currently, and with the technological apparatus, it is known that all these characteristics point to the End-Stage Renal Disease [1].

CKD is characterized by a renal lesion with progressive and irreversible loss of its glomerular, tubular and endocrine functions, translated by loss of the capacity to eliminate nitrogenous products (urea, creatinine, and uric acid), maintain extracellular volume, electrolyte concentration (sodium and potassium), balance of basic acid $(\mathrm{pH})$, osmotic pressure of the internal environment, and probably blood pressure, in addition to the production of erythropoietin and the active form of vitamin $\mathrm{D}$, responsible for bone metabolism. With its progression, the kidneys cannot maintain the normality of the patient's internal environment, leading to the onset of the terminal stage marked by the total loss of excretory capacity, becoming a carrier of chronic kidney failure $[1,2]$.

Patients with CKD, in addition to hygienic-dietary measures and medication, require renal replacement therapy, which consist of three therapeutic modalities: hemodialysis treatment (HT), peritoneal dialysis and transplantation [3-7]. HT is one of the most used, and is usually performed two to three times a week, with each session lasts an average of four hours. In addition to attending sessions, patients also need to follow a strict nutritional diet, often suffering from water deprivation, avoiding sodium foods, condiments, raw fruits and vegetables (due to the presence of potassium), as well as take various medicines [3-5, 7, 8].

According to the Brazilian Society of Nephrology, in its last census, there is an estimate of 122,825 patients undergoing dialysis treatment [9], therefore CKD is considered a public health issue [10-12]. When initiating HT, adherence to treatment must be permanent to all guidelines. Medical prescriptions to patients in HT cause changes in their daily routine. Additionally, attending the hemodialysis sessions deprives them from social and familiar conviviality; numerous nutritional restrictions do not favor the patients' palate; and water deprivation causes physical and psychological damages. Although the use of medications may cause undesirable symptoms, one believes that they may reduce clinical complaints $[4,8]$. Living with a chronic disease in which a positive prognosis cannot be defined and that has therapeutic proposals implying in numerous restrictions compromises autonomy and causes emotional suffering, often presenting as minor symptoms of anxiety and depression [3, 4, 6, 8, 10-12].

Therefore, to identify minor symptoms of anxiety and depression in patients undergoing hemodialysis, and evaluate their relationship with biological and sociodemographic variables is relevant, since such symptoms affect a large part of this population and causes damage to their quality of life.

\section{METHODS}

This cross-sectional study was carried out in the Hemodialysis Unit of the hospitals Irmandade da Santa Casa de Misericórdia de Marília and Irmandade da Santa Casa de Misericórdia de Tupã, São Paulo state, Brazil, and included patients under treatment by the public health system. These hemodialysis units belong to Regional Directorate of Health IX, city of Marília, which comprises a total of 62 municipalities. Each one offers care for its health micro-region. The study was approved by the Research Ethics Committee of the Medical School of Marília, under the number 51353115.6.0000.5413. All patients were guided about the objectives of the study and signed the informed consent.

Inclusion criteria were patients who underwent HT, over 18 years of age and who, in the assessment of mental state, should be self and psychically oriented and able to understand the objectives of the research and to respond to the assessment instruments. Those with sensory-perceptual alterations, disorientation in time and space, previous diagnosis of mental illness and impairment of cognitive functions were not included.

The patients were approached and invited to participate in the study during their hemodialysis section. Collection of data was performed three times 
a week in the two units, and it was limited to the first and second time of the sections in order to prevent clinical intercurrences, such as nausea, dizziness and hypotension.

A questionnaire for identification of sociodemographic and clinical characteristics and the Hospital Anxiety and Depression Scale (HADS) were applied. This scale has been used to evaluate mood disorders in patients with physical diseases, being one of the most used instruments in the world, according to the literature [13]. The overall score in each subscale ranges from 0 to 21 points and with a cut-off point 8/9. For anxiety symptoms, the sensitivity was $93.7 \%$ and specificity was $72.6 \%$; and for depression symptoms, $84.6 \%$ and $90.3 \%$ respectively.

Statistical analysis was performed using IBM SPSS Software v.20, adopting absolute frequencies for categorical variables and median or mean and standard deviation for the quantitative variables. To compare the scores according to the studied variables, unpaired Student's t test and Analysis of Variance were used when normality assumptions were met, and Mann-Whitney U test and Kruskal-Wallis test were used when the distribution did not follow this assumption. The level of significance was $5 \%$ $(\mathrm{p}<0.05)$.

\section{RESULTS}

During the study period, 280 patients underwent hemodialysis in the units under study: 98 from Santa Casa de Misericórdia/Tupã and 188 from Santa Casa de Misericórdia/Marília. Following the days and moments of data collection stipulated in the methodology, the study sample consisted of 65 hemodialytic patients, whose mean age was $57.22 \pm 13.44$ years and the majority were older than 52 years. Thirty-four patients $(52.3 \%)$ were males and $39(60 \%)$ had a partner. Only one patient $(1.5 \%)$ had higher education. Fiftyfive patients $(84.6 \%)$ were economically active and 51 patients $(78.5 \%)$ reported following a religion (Table 1).

Most patients $46(70.8 \%)$ presented hemodialysis time between one to five years and $58(89.2 \%)$ started treatment with age above 40 years. Physical exercises were infrequent. Forty-five patients (69.2\%) reported having reduced sexual libido. Regarding psychotherapeutic treatment, $59(90.8 \%)$ did not perform and 12 (18.5\%) had psychiatric follow-up. Forty-two patients $(64.6 \%)$ did not use psychiatric medication and four $(6.2 \%)$ had already used it before (Table 2).
Table 1. Relative and absolute frequency of sociodemographic characteristics of hemodialytic patients in the sample

\begin{tabular}{lcc}
\hline Characteristic & $\mathbf{n}$ & $\%$ \\
Gender & & \\
$\quad$ Female & 31 & 47.7 \\
$\quad$ Male & 34 & 52.3 \\
Age (years old) & & \\
20 to 30 & 2 & 3.1 \\
31 to 41 & 5 & 7.7 \\
42 to 52 & 19 & 29.2 \\
Over 52 & 39 & 60.0 \\
Civil status & & \\
$\quad$ With a partner & 39 & 60.0 \\
$\quad$ Without a partner & 26 & 40.0 \\
School level & & \\
Illiterate & 7 & 10.8 \\
Incomplete elementary & 22 & 33.8 \\
Complete elementary & 12 & 18.5 \\
Incomplete high school & 4 & 6.2 \\
Complete high school & 19 & 29.2 \\
Higher education & 1 & 1.5 \\
Economically active & & \\
$\quad$ No & 10 & 15.4 \\
Yes & 55 & 84.6 \\
Religious & & \\
No & & \\
Yes & 14 & 21.5 \\
\hline
\end{tabular}

Table 2. Distribution of clinical variables of hemodialytic patients in the sample

\begin{tabular}{|c|c|c|}
\hline Characteristic & $\mathbf{n}$ & $\%$ \\
\hline \multicolumn{3}{|c|}{ Hemodialictic diagostic time (years) } \\
\hline$<1$ & 12 & 18.5 \\
\hline 1 to 5 & 46 & 70.8 \\
\hline 6 to 10 & 3 & 4.6 \\
\hline 11 to 15 & 3 & 4.6 \\
\hline$>15$ & 1 & 1.5 \\
\hline \multicolumn{3}{|c|}{ Age at treatment onset (years old) } \\
\hline 15 to 19 & 1 & 1.5 \\
\hline 20 to 30 & 4 & 6.2 \\
\hline 31 to 40 & 2 & 3.1 \\
\hline Above 40 & 58 & 89.2 \\
\hline \multicolumn{3}{|l|}{ Physical exercise } \\
\hline Always & 3 & 4.6 \\
\hline Sometimes & 13 & 20.0 \\
\hline Never & 49 & 75.4 \\
\hline \multicolumn{3}{|l|}{ Reduced sexual libido } \\
\hline No & 20 & 30.8 \\
\hline Yes & 45 & 69.2 \\
\hline \multicolumn{3}{|c|}{ Psychotherapic treatment } \\
\hline No & 59 & 90.8 \\
\hline Yes & 2 & 3.1 \\
\hline Had done before & 4 & 6.2 \\
\hline \multicolumn{3}{|c|}{ Current psychiatric follow-up } \\
\hline No & 53 & 81.5 \\
\hline Yes & 12 & 18.5 \\
\hline \multicolumn{3}{|l|}{ Psychiatric medication } \\
\hline No & 42 & 64.6 \\
\hline Yes & 19 & 29.2 \\
\hline Had taken before & 4 & 6.2 \\
\hline
\end{tabular}


Forty-two (64.6\%) patients were classified as cases of anxiety, and $45(69.2 \%)$ as cases of depression (Table 3). Female patients presented anxiety scores statistically higher than male patients' scores. Patients aged 31 to 41 years and 42 to 52 years had statistically

Table 3. Classification of anxiety and depression in hemodialytic patients of the sample.

\begin{tabular}{lcc}
\hline $\begin{array}{l}\text { Hospital Anxiety and } \\
\text { Depression Scale }\end{array}$ & $\mathbf{n}(\%)$ & Mean \pm SD \\
Anxiety & & \\
$\quad$ Non-cases (0-8) & $23(35.4)$ & $4.61 \pm 2.69$ \\
$\quad$ Cases (9-21) & $42(64.6)$ & $11.76 \pm 2.18$ \\
Depression & & \\
$\quad$ Non-cases (0-18) & $20(30.8)$ & $5.70 \pm 2.38$ \\
$\quad$ Cases (9-21) & $45(69.2)$ & $11.78 \pm 1.65$ \\
\hline
\end{tabular}

$\mathrm{SD}$, standard deviation. higher mean scores of depression than patients who were aged 20 to 30 and patients who were older than 52 years. The other sociodemographic variables did not present statistically significant differences (Table 4).

The mean values of anxiety and depression scores did not vary according to the time of hemodialysis diagnosis, the age at which treatment was started and the practice of physical exercise. There was no statistically significant difference in patients who had reduced libido compared to those who did not. Patients who underwent psychotherapeutic treatment had a statistically lower mean score than patients who had already had treatment. The mean scores for patients who had psychiatric follow-up did not differ when compared to those who did not have this type of procedure. The score values are not different between those who use psychiatric medication and those who do not (Table 5).

Table 4. Anxiety and depression scores according to sociodemographic variables in hemodialytic patients.

\begin{tabular}{|c|c|c|c|c|c|c|c|c|c|}
\hline \multirow{2}{*}{ Characteristic } & \multirow{2}{*}{$\mathbf{n}$} & \multicolumn{3}{|c|}{ HADS score Anxiety } & \multirow{2}{*}{$\mathbf{p}$} & \multicolumn{3}{|c|}{ HADS Score Depression } & \multirow{2}{*}{$\mathbf{p}$} \\
\hline & & Mean & SD & Median & & Mean & SD & Median & \\
\hline \multicolumn{10}{|l|}{ Gender } \\
\hline Female & 31 & 10.23 & 4.51 & 11.00 & \multirow{2}{*}{0.034} & 10.19 & 3.93 & 11.00 & \multirow{2}{*}{0.174} \\
\hline Male & 34 & 8.32 & 3.68 & 9.00 & & 9.65 & 2.85 & 10.00 & \\
\hline \multicolumn{10}{|l|}{ Age (years old) } \\
\hline 20 to 30 & 2 & 7.50 & 2.12 & 7.50 & \multirow{4}{*}{0.390} & $5.50^{*}$ & 2.12 & 5.50 & \multirow{4}{*}{0.017} \\
\hline 31 to 41 & 5 & 11.40 & 3.29 & 9.00 & & $12.20 *$ & 1.48 & 12.00 & \\
\hline 42 to 52 & 19 & 10.11 & 2.99 & 11.00 & & $11.16^{*}$ & 2.50 & 12.00 & \\
\hline above 52 & 39 & 8,62 & 4.72 & 10.00 & & 9.23 & 3.63 & 10.00 & \\
\hline \multicolumn{10}{|l|}{ Civil status } \\
\hline With partner & 39 & 8.33 & 4.08 & 10.00 & \multirow{2}{*}{0.063} & 9.56 & 3.43 & 10.00 & \multirow{2}{*}{0.329} \\
\hline Without partner & 26 & 10.58 & 4.01 & 10.00 & & 10.42 & 3.34 & 11.00 & \\
\hline \multicolumn{10}{|l|}{ School level } \\
\hline Illiterate & 7 & 8.14 & 4.37 & 7.00 & \multirow{6}{*}{0.151} & 10.43 & 2.93 & 11.00 & \multirow{6}{*}{0.124} \\
\hline Incomplete el. & 22 & 8.64 & 4.66 & 9.50 & & 9.41 & 3.80 & 10.00 & \\
\hline Complete el. & 12 & 11.50 & 4.01 & 12.00 & & 10.25 & 2.80 & 10.50 & \\
\hline Incomplete HS & 4 & 10.00 & 2.16 & 10.50 & & 13.00 & 0.81 & 13.00 & \\
\hline Complete HS & 19 & 9.21 & 3.22 & 9.00 & & 9.95 & 2.89 & 11.00 & \\
\hline Complete HE & 1 & 0.00 & - & 0.00 & & 0.00 & - & 0.00 & \\
\hline \multicolumn{10}{|l|}{ Economically active } \\
\hline No & 10 & 10.70 & 5.03 & 11.50 & \multirow{2}{*}{0.155} & 9.70 & 4.32 & 11.00 & \multirow{2}{*}{0.812} \\
\hline Yes & 55 & 8.96 & 3.99 & 10.00 & & 9.95 & 3.25 & 11.00 & \\
\hline \multicolumn{10}{|l|}{ Religious } \\
\hline No & 14 & 10.14 & 3.06 & 10.50 & \multirow{2}{*}{0.461} & 10.79 & 3.06 & 11.50 & \multirow{2}{*}{0.365} \\
\hline Yes & 51 & 8.98 & 4.42 & 10.00 & & 9.67 & 3.47 & 11.00 & \\
\hline
\end{tabular}

HADS, Hospital Anxiety and Depression Scale; el, elementary; HS, high school; HE, higher education. MannWhitney U or Kruskal-Wallis tests. 
Table 5. Hospital Anxiety and Depression Scale scores of anxiety and depression according to sociodemographic variables in hemodialytic patients.

\begin{tabular}{|c|c|c|c|c|c|c|c|c|c|}
\hline \multirow{2}{*}{ Characteristic } & \multirow[t]{2}{*}{$\mathbf{n}$} & \multicolumn{3}{|c|}{$\begin{array}{l}\text { HADS score } \\
\text { Anxiety }\end{array}$} & \multirow{2}{*}{$\mathbf{p}$} & \multicolumn{3}{|c|}{$\begin{array}{l}\text { HADS score } \\
\text { Depression }\end{array}$} & \multirow[t]{2}{*}{$\mathbf{p}$} \\
\hline & & Mean & SD & Median & & Mean & SD & Median & \\
\hline \multicolumn{10}{|c|}{ Hemodialictic diagostic time (years) } \\
\hline$<1$ & 12 & 8.92 & 4.20 & 10.00 & \multirow{5}{*}{0.420} & 10.42 & 3.14 & 11.00 & \multirow{5}{*}{0.707} \\
\hline 1 to 5 & 46 & 9.48 & 4.10 & 10.00 & & 9.61 & 3.59 & 10.50 & \\
\hline 6 to 10 & 3 & 5.33 & 5.03 & 6.00 & & 11.67 & 3.21 & 13.00 & \\
\hline 11 to 15 & 3 & 11.33 & 4.72 & 13.00 & & 10.00 & 2.00 & 10.00 & \\
\hline$>15$ & 1 & 7.00 & . & 7.00 & & 12.00 & . & 12.00 & \\
\hline \multicolumn{10}{|c|}{ Age at treatment onset (years old) } \\
\hline 15 to 19 & 1 & 6.00 & . & 6.00 & \multirow{4}{*}{0.621} & 4.00 & . & 4.00 & \multirow{4}{*}{0.145} \\
\hline 20 to 30 & 4 & 10.50 & 3.00 & 9.00 & & 11.00 & 2.70 & 12.00 & \\
\hline 31 to 40 & 2 & 8.00 & 1.41 & 8.00 & & 13.00 & 1.41 & 13.00 & \\
\hline Above 40 & 58 & 9.24 & 4.32 & 10.00 & & 9.83 & 3.39 & 10.50 & \\
\hline \multicolumn{10}{|l|}{ Physical exercise } \\
\hline Always & 3 & 5.67 & 3.21 & 7.00 & \multirow{3}{*}{0.228} & 7.00 & 4.35 & 5.00 & \multirow{3}{*}{0.250} \\
\hline Sometimes & 13 & 8.92 & 4.42 & 9.00 & & 9.23 & 3.39 & 9.00 & \\
\hline Never & 49 & 9.53 & 4.12 & 10.00 & & 10.27 & 3.30 & 11.00 & \\
\hline \multicolumn{10}{|l|}{ Reduced sexual libido } \\
\hline No & 20 & 9.20 & 5.14 & 9.50 & \multirow{2}{*}{0.864} & 9.30 & 4.50 & 11.00 & \multirow{2}{*}{0.780} \\
\hline Yes & 45 & 9.24 & 3.73 & 10.00 & & 10.18 & 2.79 & 10.00 & \\
\hline \multicolumn{10}{|c|}{ Psychotherapic treatment } \\
\hline No & 59 & 9.27 & 3.92 & 10.00 & \multirow{3}{*}{0.020} & 10.14 & 3.07 & 11.00 & \multirow{3}{*}{0.107} \\
\hline Yes & 2 & 1.00 & 1.41 & 1.00 & & 3.00 & 4.24 & 3.00 & \\
\hline Had done before & 4 & 12.75 & 3.40 & 13.50 & & 10.00 & 4.96 & 10.00 & \\
\hline \multicolumn{10}{|l|}{ Psychiatric follow-up } \\
\hline No & 53 & 8.75 & 4.03 & 10.00 & \multirow{2}{*}{0.050} & 9.89 & 3.45 & 11.00 & \multirow{2}{*}{0.912} \\
\hline Yes & 12 & 11.33 & 4.29 & 12.00 & & 10.00 & 3.27 & 11.00 & \\
\hline \multicolumn{10}{|l|}{ Psychiatric medication } \\
\hline No & 42 & 9.05 & 3.85 & 10.00 & \multirow{3}{*}{0.699} & 10.33 & 2.86 & 11.00 & \multirow{3}{*}{0.628} \\
\hline Yes & 19 & 9.32 & 5.07 & 11.00 & & 9.05 & 4.44 & 10.00 & \\
\hline Had taken before & 4 & 10.75 & 3.30 & 10.50 & & 9.50 & 2.88 & 9.50 & \\
\hline
\end{tabular}

HADS: Hospital Anxiety and Depression Scale. MannWhitney U or Kruskal-Wallis test.

\section{DISCUSSION}

Considering the increasing prevalence of CKD, it is relevant to understand the whole health needs of this population. In this sense, identifying the minor symptoms of anxiety and depression allows us to consider the construction of therapeutic strategies that favour the quality of life of these patients.

Many subjects of this sample were in their productive age and, due to the disease, their daily activities might be compromised, including significant psychosocial losses such as difficulty in maintaining their social bonds (due to intense hospital routine). In addition to the loss of their labour activities, changes in their body image may occur (swelling, discoloration of the skin, halitosis, alopecia and the appearance of fistula), with loss of social functions and imminence of death $[10,11,14]$. Therefore, it is worth to observe that in the clinical practice during the process of illness, social support should be considered as an important element for the treatment and biopsychosocial rehabilitation of the patient.

Patients with CKD may have a reduction in sexual libido, identified in this sample as $69.2 \%$ with this symptomatology. Sexual libido is understood by psychoanalytic theory as a drive for life, which 
leads the subject to the recognition of himself/herself, his/her desires and that which can be produced by $\mathrm{him} / \mathrm{her}$. Thus, the reduction of the sexual libido awakens feelings of loss of satisfaction/pleasure, and feelings of helplessness [15-17]. Studies by Dalgalarrondo [18] and Gabbard [19] show that there is a predominant presence of depressive symptoms in the general population, which can be observed in the neurovegetative dimensions, and may be associated with decreased sexual libido, erectile dysfunction, delayed orgasm or anorgasmia.

We observed that $75.4 \%$ of the sample stated not to practice physical exercises. Physical exercise can offer improvement in functional capacity, muscle strength and increases the effectiveness of HT. Patients that performed isotonic exercises during the hemodialysis session showed an improvement in the urea clearance index $(\mathrm{Kt} / \mathrm{V})$ [4, 20-25].

The present sample of hemodialytic patients has a large number of anxiety and depression cases, as well as other studies, which also report this finding $[3,6,10,14,26]$. Parallel to this, patients between 21 to 30 years and over 52 years of age presented lower scores for anxiety and depression, when compared to the age groups of 31 to 40 and 41 to 52 years. Younger patients may have an expectancy of longevity, and those with more advanced ages have several lifelong experiences that can provide a greater resilience to the chronicity of a disease.

Women presented a highest rate of anxiety symptoms. Despite the scarcity of studies regarding specifically CKD, we know that the female gender usually presents a higher level of anxiety [4]. This fact may be related to the social role that women need to play nowadays, whether as mother, wife, worker and home care provider. Therefore, due to chronicity of HT and of all biopsychosocial repercussions, it is possible that anxiety arises as a response of the organism to the actual losses and imminence of death.

The highest depression scores were observed in the age group between 31 and 41 years and 42 to 52 years. Coutinho and Costa [6] observed the existence of $20 \%$ of depressive symptoms among patients, but in a wider age group than our sample, from 20 to 73 years. In that study, it was observed that patients experienced changes in their life routines. Minor symptoms of anxiety and depression may affect the biopsychosocial dimensions [27]. This fact directly interferes with social coexistence and the possibility of autonomy, still possible in productive age.
Thus, it is understood that our sample is in the relatively young age group and, faced with the impact of a terminal illness, experiences the interruption of life autonomy and frustration for having their plans interrupted. These feelings of frustration can generate and, simultaneously, can be enhanced by the side effects that HT can cause to these patients. According to Carvalho and Barbosa [15], other physical symptoms may be present, among them fatigue, a common condition in CKD. However, this may also be a suggestive element for a depressive illness $[3,4,15]$.

There was no statistically significant difference between patients taking or using psychiatric medications and patients with or without psychiatric treatment. However, there was a statistically significant difference among patients who underwent psychotherapeutic treatment when compared to those who did not and those who did it at some point. Psychotherapy offers conditions for the patient with CKD to re-signify the moment in which he is living and offers him a support. According to Cordioli [28], psychotherapy, as a treatment modality, has stood out due to the positive results $[19,25]$. Specifically in patients undergoing HT, effectiveness of psychotherapy, regarding improvement in the quality of life, is observed [25,28].

We believe that new studies that could better approach the therapeutic management of symptoms of anxiety and depression in HD patients (whether from psychosocial or psychoactive drug approaches) will be relevant. For a better understanding of the studied population, increasing the size of the sample is deemed necessary, as it was below the initial proposal. Due to the results of our sample, in which the women presented minor anxiety symptoms, limitations for comparing this information were found due to the scarcity of specialized literature on this theme. However, it is known that women usually present a higher level of anxiety [25], which may be related to the social role that women currently play as mothers, wives, workers and providers of domestic care.

With the high prevalence of minor anxiety and depression symptoms in patients with CKD submitted to HT, we must reflect on the therapeutic practice offered to these patients. We suggest better conditions for patients to be able to face the difficulties and limitations. More complete teams, with interdisciplinary approach, are needed. Professionals with specialized training can contribute to the demands that extrapolate exclusively medical care. Thus, multidisciplinary teams (nurses, psychologists, social workers, physical education professionals, occupational therapists and 
physiotherapists) can share with the medical team a holistic understanding and offer a reduction in the iatrogenic effects of HT.

\section{NOTES}

\section{Acknowledgments}

Our thanks to the patients of the Hemodialysis Units of Santa Casa de Misericórdia de Marília and Santa Casa de Misericórdia de Tupã.

\section{Funding}

This study did not receive financial support from outside sources.
Conflicts of interest disclosure

The authors declare no competing interests relevant to the content of this study.

\section{Authors' contributions}

All the authors declare to have made substantial contributions to the conception, or design, or acquisition, or analysis, or interpretation of data; and drafting the work or revising it critically for important intellectual content; and to approve the version to be published.

\section{Availability of data and responsibility for the results}

All the authors declare to have had full access to the available data and they assume full responsibility for the integrity of these results.

\section{REFERENCES}

1. Riella MC. Princípios de nefrologia e distúrbios hidroeletrolíticos. 5a ed. Rio de Janeiro: Guanabara Koogan; 2010.

2. Cigarroa I, Barriga R, Michéas C, Zapata-Lamana R, Soto C, Manukian T. Effects of a resistance training program in patients with chronic kidney disease on hemodialysis. Rev Med Chile. 2016;144:844-52. https://doi.org/10.4067/S003498872016000700004

3. Pereira BS, Fernandes NS, Melo NP, Abrita R, Grincenkov FRS, Fernandes NMS. Beyond quality of life: a cross sectional study on the mental health of patients with chronic kidney disease undergoing dialysis and their caregivers. Health Qual Life Outcomes. 2017;15(1):74. https://doi.org/10.1186/s12955-017-0646-4

4. Dziubek W, Kowalska J, Kusztal M, Rogowski Ł, Gołębiowski T, Nikifur M, Szczepańska-Gieracha J, Zembroń-Łacny A, Klinger M, Woźniewski M. The level of anxiety and depression in dialysis patients undertaking regular physical exercise training - a preliminar study. Kidney Blood Press Res. 2016;41(1):86-98. https://doi.org/10.1159/000368548

5. D’Onofrio G, Simeoni M, Rizza P, Caroleo M, Capria M, Mazzitello G, Sacco T, Mazzuca E, Panzino MT, Cerantonio A, Segura-Garcia C, Andreucci M, De Fazio P, Fuiano G. Quality of life, clinical outcome, personality and coping in chronic hemodialysis patients. Renal Fail. 2016;39(1):45-53. https://doi.org/10.1080/0886022X.2016.1244077

6. Coutinho MPL, Costa FG. Depression and chronic renal failure: a socio-psychological analysis. Psicol Soc. 2015;27(2): 449-59. https://doi.org/10.1590/1807-03102015v27n2p449

7. Ibrahim S, Hossam M, Belal D. Study of non-compliance among chronic hemodialysis patients and its impact on patients' outcomes. Saudi J Kidney Dis Transpl. 2015;26(2):243-9. https://doi.org/10.4103/1319-2442.152405

8. Rahimimoghadam Z, Rahemi Z, Ajorpaz NM, Sadat Z. Effects of pilates exercise on general health of hemodialysis patients. J Bodyw Mov Ther. 2017;21(1):86-92. https://doi.org/10.1016/j.jbmt.2016.05.012

9. Sesso RC, Lopes AA, Thomé FS, Lugon JR, Martins CT. Brazilian chornic dialysis survey 2016. J Bras Nefrol. 2017;39(3):261-6. https://doi.org/10.5935/0101-2800.20170049

10. Olagunju AT, Campbell EA, Adeyemi JD. Interplay of anxiety and depression with quality of life in endstage renal disease. Psychosomatics. 2015;56(1):67-77. https://doi.org/10.1016/j.psym.2014.03.006

11. Andrade SV, Sesso R, Diniz DHMP. Hopelessness, suicide ideation, and depression in chronic kidney disease patients on hemodialysis or transplant recipientes. J Bras Nefrol. 2015;37(1):55-63. https://doi.org/10.5935/0101-2800.20150009

12. Murillo-Zamora E, Macías-de la Torre AA, Higareda-Almaraz MA. Depression prevalence among end stage renal disease patients in maintenance hemodialysis. Rev Med Inst Mex Seguro Soc. 2016;54(4):429-33.

13. Botega NJ, Bio MR, Zomignani MA, Garcia JC, Pereira WA. Mood disorders among medical in-patients: a validation study of the hospital anxiety and depression scale (HAD). Rev Saude Publica. 1995;29(5):355-63.

14. Macedo LOS, Teixeira MGFD. Experienced changes in chronic kidney disease: impact on the perception of self-image and sexuality. Rev Saúde Desenvolv. 2016;9(5):165-77.

15. Carvalho AR, Barbosa MR. Depression in hemodialysis patients: the role of body satisfaction and sexuality. Rev Port Saúde Pública 2016;34(2):144-53. https://doi.org/10.1016/j.rpsp.2016.02.002

16. Saglimbene V, Natale P, Palmer S, Scardapane M, Craig JC, Ruospo M, Gargano L, Lucisano G, Török M, Celia E, Gelfman R, Bednarek-Skublewska A, Dulawa J, Stroumza P, Leal M, Del Castillo D, Murgo AM, Schon S, Wollheim C, Hegbrant J, Strippoli GFM. The prevalence and correlates of low sexual functioning in women on hemodialysis: a multinational, cross-sectional study. PLoS One. 2017;12(6):e0179511. https://doi.org/10.1371/journal.pone.0179511

17. Aribi L, Masmoudi R, Ben Houidi A, Charfeddine F, Jarraya F, Hachicha J, Amami O. Sexual disorders in patients hemodialysis. Tunis Méd. 2015;93(2):79-84.

18. Dalgalarrondo P. Psicopatologia e semiologia dos transtornos mentais. $2^{\underline{a}}$ ed. Porto Alegre: Artmed; 2008. 
19. Gabbard GO. Psiquiatria psicodinâmica na prática clínica. 4aㅡ ed. Porto Alegre: Artmed; 2006.

20. Freire APCF, Rios CS, Moura RS, Burneiko RCVM, Padulla SAT, Lopes FS. Isotonic exercise during hemodialysis improves dialysis efficiency. Fisioter Mov 2013;26(1):167-74. https://doi.org/10.1590/S0103-51502013000100019

21. Abreu CC, Cardozo LFMF, Stockler-Pinto MB, Esgalhado M, Barboza JE, Frauches R, Mafra D. Does resistance exercise performed during dialysis modulate Nrf2 and NF-kB in patients with chronic kidney disease? Life Sci. 2017;188:192-7. https://doi.org/10.1016/j.1fs.2017.09.007

22. Chan JH, Koo M, Wu SW, Chen CY. Effects of a 12-week program of Tai Chi exercise on the kidney disease quality of life and physical functioning of patients with end-stage renal disease on hemodialysis. Complement Ther Med. 2017;30: 79-83. https://doi.org/10.1016/j.ctim.2016.12.002

23. Olvera-Soto MG, Valdez-Ortiz R, López Alvarenga JC, Espinosa-Cuevas ML. Effect of resistance exercises on the indicators of muscle reserves and handgrip strength in adult patients on hemodialysis. J Ren Nutr 2016;26(1):53-60. https://doi.org/10.1053/j.jrn.2015.06.006

24. Katayama A, Miyatake N, Nishi H, Ujike K, Hashimoto H, Kurato R, Koumoto K. Relationship between changes in physical activity and changes in health-related quality of life in patients on chronic hemodialysis with 1-year follow-up. Acta Med Okayama. 2016;70(5):353-61.

25. Phan K, Jia F, Kamper SJ. Effects of regular physical exercise training in adults with chronic kidney disease. Br J Sports Med. 2016;50(5):317-8. https://doi.org/10.1136/bjsports-2015-095240

26. Ng HJ, Tan WJ, Mooppil N, Newman S, Griva K. Prevalence and patterns of depression and anxiety in hemodialysis patients: A 12-month prospective study on incidente and prevalente populations. Br J Health Psychol. 2015; 20(2): 374-95. https://doi.org/10.1111/bjhp.12106

27. Palmer SC, Natale P, Ruospo M, Saglimbene VM, Rabindranath KS, Craig JC, Strippoli GF. Antidepressants for treating depression in adults with end-stage kidney disease treated with dialysis. Cochrane Database Syst Rev. 2016;(5):CD004541. https://doi.org/10.1002/14651858.CD004541.pub3

28. Cordioli AV. Como atuam as psicoterapias. In: Cordioli AV, organizador. Psicoterapias: abordagens atuais. Porto Alegre: Artmed; 2008. p. 42-57. 